Journal of Marine Systems

July 2008, Volume 72, Issues 1-4, Pages 309-319 http://dx.doi.org/10.1016/j.jmarsys.2007.03.010

(c) 2008 Elsevier B.V. All rights reserved.
Archimer, archive institutionnelle de l'Ifremer http://www.ifremer.fr/docelec/

\title{
Seasonal variation of riverine nutrient inputs in the northern Bay of Biscay (France), and patterns of marine phytoplankton response
}

\author{
Jean-François Guillaud ${ }^{\mathrm{a},{ }^{*}}$, Alain Aminot ${ }^{\mathrm{a}}$, Daniel Delmas ${ }^{\mathrm{b}}$, Francis Gohin ${ }^{\mathrm{a}}$, Michel Lunven ${ }^{\mathrm{a}}$, \\ Claire Labry ${ }^{\mathrm{a}}$, Alain Herbland ${ }^{\mathrm{c}}$
}

${ }^{a}$ IFREMER, Dep ${ }^{t}$ DYNECO, BP 70, 29280 Plouzané, France

${ }^{\mathrm{b}}$ IFREMER, Dep ${ }^{\mathrm{t}}$ AGSAE, BP 7, 17137 I'Houmeau, France

${ }^{c}$ IFREMER, Dep ${ }^{t}$ AQUACAL BP 2059, 98846 Nouméa Cedex, Nouvelle-Calédonie

* Corresponding author: Tel: 332982243 46; Fax: 3329822 45 48, email address :

Jean.Francois.Guillaud@ifremer.fr

\begin{abstract}
:
Seasonal variations in nutrient inputs are described for the main rivers (Loire and Vilaine) flowing into the northern Bay of Biscay. The river plumes are high in N/P ratio in late winter and spring, but not in the inner plume during the summer. Conservative behavior results in most nutrients entering the estuary and eventually reaching the coastal zone. Temporal and spatial aspects of phytoplankton growth and nutrient uptake in the northern Bay of Biscay distinguish the central area of salinity 34 from the plume area. The first diatom bloom appears offshore in late winter, at the edge of the river plumes, taking advantage of haline stratification and anticyclonic "weather windows." In spring, when the central area of the northern shelf is phosphorus-limited, small cells predominate in the phytoplankton community and compete with bacteria for both mineral and organic phosphorus. At that period, river plumes are less extensive than in winter, but local nutrient enrichment at the river mouth allows diatom growth. In summer, phytoplankton become nitrogen-limited in the river plumes; the central area of the shelf is occupied by small forms of phytoplankton, which are located on the thermocline and use predominantly regenerated nutrients.
\end{abstract}

Keywords: Nutrients, riverine inputs, continental shelf, phytoplankton, Northern Bay of Biscay 


\section{Introduction}

The northern Bay of Biscay is located in the northeastern Atlantic off France (between $47^{\circ} \mathrm{N}$ and $48^{\circ} \mathrm{N}$ and $2^{\circ} \mathrm{E}$ and $6^{\circ} \mathrm{E}$ ). This part of the Bay of Biscay receives fresh water from the Loire and Vilaine rivers whose watershed areas $\left(128800 \mathrm{~km}^{2}\right)$ account for $95 \%$ of the total catchment area of the northern Bay of Biscay. The mean annual river flows are $835 \mathrm{~m}^{3} \mathrm{~s}^{-1}$ and $75 \mathrm{~m}^{3} \mathrm{~s}^{-1}$ for the Loire and the Vilaine, respectively (OSPAR Commission, 2000). Many studies have documented the hydrodynamics of this area. Haline stratification is strong from February to June in response to high river runoff and relatively low vertical mixing; thermal stratification occurs between May and midSeptember in a $\sim 50 \mathrm{~m}$ thick layer, whereas the water column remains thermally homogenous from January to the beginning of April (summarized from Koutsikopoulos and Le Cann, 1996; Lazure and Jegou, 1998; Puillat et al., 2004).

The biogeochemical functioning of the northern continental shelf is also partially known. The extent and consequences of these continental loadings for nutrient and chlorophyll distribution were determined (Lampert et al. 2002; Loyer et al. 2006): the freshwater inputs induce a nitrate gradient from river mouths to offshore waters in the vicinity of the $100 \mathrm{~m}$ isobath. The situation in early spring is characterized by high N/P molar ratios in front of the Loire and Vilaine estuaries which highlight the nitrate excess in river loadings. Phytoplankton mainly develops once haline or thermal stratification is established (Morin et al., 1991). The outflow of continental waters from the Loire and Vilaine estuaries modifies the hydrographic patterns in the northern Bay of Biscay. From January to June, the haline stratification is strong on a large part of the shelf in response to high Loire river runoff. During flooding, mesoscale structures, such as expanded river plumes or low salinity lenses, occur. Between May and September, thermal stratification occurs in a layer that can reach $50 \mathrm{~m}$ in thickness (Puillat et al., 2004). These driving physical variables, associated with riverine nutrient inputs and meteorological conditions (particularly solar irradiance), can influence seasonal phytoplankton behavior in the Northern Bay of Biscay.

In the southern part of the Bay of Biscay, the Gironde's discharge affects the timing of primary production as well as the structure of the phytoplankton community. Late winter phytoplankton blooms often begin at the edge of the Gironde plume, related to the haline stratification and anticyclonic "window" after mid-February (Labry et al., 2001, 2002). Thanks to satellite imagery, this phenomenon is also been observed once on the northern part of the continental shelf in late winter 2000 (Gohin et al., 2003), but its development is not as well known as in the southern Bay of Biscay.

The phytoplankton response to riverine inputs has not been studied in the northern Bay of Biscay to the same extent as in the North, Baltic and northern Adriatic Seas (Wassmann and Olli, pers. com., 2004; Nausch et al., 1999; Vollenweider et al., 1998).

This study aimed to (i) estimate the annual variability of nutrient concentrations in the two main rivers, (ii) show how nutrients behave throughout the estuarine system, and (iii) describe the main seasonal feature of nutrients and phytoplankton in the northern Bay of Biscay affected by freshwater discharge.

\section{Materials and methods}

\subsection{Sampling strategy}

The values of daily river flows are given by the "Banque Nationale des Données pour l'Hydrométrie et l'Hydrologie" (http://www.hydro.eaufrance.fr/accueil.html), and the nutrient concentrations (N, P, Si) in river water are provided twice per month by the Agence de l'Eau LoireBretagne (http://www.eau-loire-bretagne.fr/) water board in the two river stations located upstream of the haline intrusion, at Sainte-Luce (near the city of Nantes) in the Loire river, and at Rieux (near the city of Redon) in the Vilaine river (Fig. 1).

\section{Location of Fig. 1}

Estuarine and marine data were provided by three oceanographic surveys. The late winter "Nutrigas" cruise took place from February $22^{\text {nd }}$ to March $4{ }^{\text {th }} 2001$ aboard the Thalassa; the spring 
"Gasprod" cruise from April $8^{\text {th }}$ to $21^{\text {st }} 2002$ on the same vessel and the summer "Viloir" survey from June $19^{\text {th }}$ to $26^{\text {th }} 2003$ aboard the Côtes de la Manche. Sampling was performed on 42 marine stations located from nearshore to offshore waters (depth $150 \mathrm{~m}$ ) and 10 estuarine stations for salinity ranging from 30 to 0.5 (Fig. 1). During the early summer cruise, the river plumes were less extensive and the sampling strategy focused on 23 marine stations off the river mouths. At each station, samples were taken at different depths in order to describe the vertical structure of the water column. Measurements were made using a profiler with a SBE25 CTD probe (Sea-Bird Electronics, Washington, USA), a fluorescence sensor (Seapoint, Exeter, USA), and a SBE 32 carrousel water sampler of 12 8-l Niskin bottles (Sea-Bird Electronics, Washington, USA). This profiler records depth, temperature, salinity, chlorophyll-like fluorescence, optical back-scattering and photo-synthetically available radiation (PAR).

A Fine Scale Sampler (FSS) was also used in the Loire river plume during spring and summer cruises in order to study phytoplankton distribution in highly stratified water columns. The FSS consists of a linear array of 15 sampling bottles, horizontally set at $20 \mathrm{~cm}$ intervals (see Lunven et al., 2005).

Finally, satellite imagery was used by applying ocean color techniques to the data of the Seaviewing Wide Field-of-view Sensor (SeaWiFS); it has been providing very useful data for monitoring phytoplankton biomasses in clear waters. For coastal waters, where the optical properties are due in part to scattering and absorption by mineral suspended matter or coloured dissolved organic material (CDOM) from land, the chlorophyll concentration can only be approximated. An empirical case 2 water algorithm calibrated on in situ data measured in the English Channel and in the Bay of Biscay has been successfully used by Gohin et al. (2002).

\subsection{Statistical method used for the assessment of river nutrient seasonal variation}

Correlation analyses between river flow and river nutrient concentrations were performed similar to Jarvie et al. (2005) on the river Avon (UK) for nitrate and total reactive phosphorus, Dolezal and Kvitek (2004) for nitrate in the Kopaninky catchment (Czech Republic), and Aminot et al. (1993) for phosphate in the Seine river $(\mathrm{F})$.

\subsection{Analytical methods}

A quantitative estimation of in situ chlorophyll $a$ was performed by computing the relationship between in situ fluorescence and laboratory chlorophyll $a$ values. For the three seasonal cruises, the calculated relationships were applied to all in situ fluorometric data (for example the relationship during "Nutrigas" cruise was: Chloro $a=1.28 *$ fluo $+0.12 ; \mathrm{R}^{2}=0.83$ ). Total chlorophyll $a$ (chl $a$ ) and phaeopigments (Phae) were determined by filtering seawater through $47 \mathrm{~mm}$ Whatman GF/F membranes. Size fractionation was achieved during the Gasprod cruise; total chl $a$ was then measured by filtration on $0.4 \mu \mathrm{m}$ Nuclepore polycarbonate filters, size fraction limits being respectively $3 \mu \mathrm{m}$ (Nuclepore polycarbonate filters) and $20 \mu \mathrm{m}$ (nylon sieve). The filters were frozen and later analyzed by the fluorometric acidification procedure (Holm-Hansen et al. 1965). Samples for nutrient measurement $\left(\mathrm{NO}_{3}, \mathrm{NO}_{2}, \mathrm{NH}_{4}, \mathrm{PO}_{4}\right)$ were filtered in-line through a Gelman $10 \mu \mathrm{m}$ polypropylene membrane and quickly frozen $\left(-25^{\circ} \mathrm{C}\right)$. For silicate, the water was filtered through $0.8 \mu \mathrm{m}$ cellulose nitrate membranes, using an all-plastic device, and preserved by adding mercuric chloride $\left(20 \mathrm{mg} \mathrm{l}^{-1}\right)$. Analyses were performed in the laboratory using a Technicon Autoanalyzer according to Tréguer and Le Corre (1975) for $\mathrm{NO}_{3}, \mathrm{NO}_{2}, \mathrm{PO}_{4}$ and $\mathrm{Si}(\mathrm{OH})_{4} . \mathrm{NH}_{4}$ was measured according to Kerouel and Aminot (1997). Phytoplankton samples for species counts were preserved in a lugol-glutaraldehyde solution (1\%), and their abundance was counted using an inverted microscope.

Finally ${ }^{33} \mathrm{PO}_{4}{ }^{3-}$ incorporation and incubation experiments were realized on the deck of the ship in quasi in-situ conditions during the spring cruise (Labry et al., 2002); they allowed to calculate the turnover time of orthophosphate in water samples (Thingstad et al., 1993). 


\section{Results}

\subsection{Riverine nutrient inputs}

The plot of dissolved inorganic nitrogen (DIN $\left.=\mathrm{NO}_{3}+\mathrm{NO}_{2}+\mathrm{NH}_{4}\right)$ since 1994 in the Loire river versus the river flow is shown on fig. 2; it gives an example of a classical relationship previously pointed out by Sigleo and Frick (in press). The same approach conducted on the Vilaine river indicated the same pattern.

\section{Location of Fig. 2}

The plot of dissolved inorganic phosphate (DIP) versus the river flow (Q) highlights the increase of concentrations in the Loire with discharge (fig. 3). During the summer with low river flow, nutrients, and particularly phosphate, are taken up by phytoplankton in the freshwater river where phosphorus is the first limiting nutrient (Kölher, 2006)

\section{Location of Fig. 3}

With regard to dissolved silica concentrations, the relationship with river flow is positive because of weathering of the watershed during floods and riverine phytoplankton uptake in summer (Hem, 1989)

\section{Location of Fig. 4}

The table 1 gives the annual riverine nutrient inputs observed in 2004.

\section{Location of Table 1}

Finally the N/P molar ratios in Loire river water were calculated. The lowest values correspond to low river flow because of (i) the prevailing role of constant urban point sources in phosphorus fluxes and (ii) the decrease of nitrogen leaching during low river flow (Sigleo and Frick, in press). During high river flow the N/P ratios were high and quasi-constant because of concomitant increase of $\mathrm{N}$ and $\mathrm{P}$ concentrations during floods (Fig. 5).

\section{Location of Fig. 5}

During the summer, when the river flow is weak, the N/P ratio can decrease under the Redfield ratio of 16 and nitrogen can be the limiting nutrient. On the contrary, during the other seasons with moderate or high river flow, the values of the N/P ratio are frequently higher than 16 and show that phosphate is the potential limiting nutrient. The same results were obtained for the N/P ratios in the Vilaine river.

\subsection{Behavior of nutrients within the Loire estuary}

For all seasons, conservative behavior of nutrients along the salinity gradient was evident, suggesting that no large sinks or sources of nutrients were occurring within the estuary (Fig. 6); it appears that most of the dissolved inorganic nitrogen and silicate entering the estuary reaches the coastal zone, similar to the Seine estuary (Guillaud, 1983; Aminot et al., 1998) because of the relatively low residence time of fresh water within the Loire estuary, ranging from 3 days in floods to 30 days at low river flow (Gallenne, 1974). According to Cloern (2001), these low residence times result in nitrogen export between $75 \%$ and $95 \%$ of the input.

\section{Location of Fig. 6}

The main exception was an increase of phosphate concentrations within the estuary because of (i) Nantes' urban wastewater disposal (2.5 $\mathrm{t} \mathrm{d}^{-1}$ of phosphorus), and (ii) the potential desorption of 
exchangeable particulate phosphate from the estuarine turbidity maximum in spring tide or from the fluid mud in neap tide (Rincé et al., 1985).

At the mouth of the Loire estuary (with salinities between 32.5 and 33.5), the N/P ratios were calculated and could be compared with the Redfield ratio. Their values in late winter $(\mathrm{N} / \mathrm{P}=50)$ and in spring $(\mathrm{N} / \mathrm{P}=70)$ indicate a relative surplus of nitrogen input in comparison with $\mathrm{P}$ input to the coastal zone. On the contrary, the low value observed in summer $(\mathrm{N} / \mathrm{P}=6.6)$ indicates a potential deficit of nitrogen in the plume area. This seasonal switch is observed in the lower part of many estuaries (Peeters and Peperzak, 1990; Conley D. J., 2000; Guillaud et al., 2000; Kemp et al., 2005).

\subsection{Seasonal phytoplankton behavior in the northern Bay of Biscay}

\subsubsection{The late winter situation}

At the end of February 2001, during the "Nutrigas" winter cruise, the Loire river flow was high and ranged from $1060 \mathrm{~m}^{3} \mathrm{~s}^{-1}$ to $948 \mathrm{~m}^{3} \mathrm{~s}^{-1}$; a phytoplankton bloom was observed at the edge of the Loire river plume. The chlorophyll $a$ reached $5 \mu \mathrm{g} \mathrm{l}^{-1}$ in the central bloom area (Fig. 7).

\section{Location of Fig. 7}

The haline stratification resulted in a surface mixed layer of $25 \mathrm{~m}$. Morin et al. (1991) showed that a simple model of critical depth (Riley, 1957) taking into account the overall solar irradiance and the depth of the mixed layer is theoretically sufficient to explain the early bloom in the central area of the northern shelf. During the late winter cruise, anticyclonic weather conditions prevailed for ten days and offered maximal solar irradiance on the shelf area. Moreover, the lower turbidity in this area, compared to the coastal zone, allowed the early bloom of phytoplankton. A similar phenomenon was observed at the edge of the Gironde plume in 1998 by Labry et al. (2001), but with lower concentrations of chlorophyll $a$. Thanks to satellite imagery, Gohin et al. (2003) observed a similar phytoplankton bloom in late winter 2000 on the continental shelf offshore from southern Brittany. Using same method, Huret (2005) shown that the late winter phytoplankton blooms in the southern Bay of Biscay were narrower and lower than in the Northern Bay.

The phytoplankton was dominated by large diatoms, as shown in other late winter blooms previously observed in the southern Bay of Biscay (Labry et al., 2001).

The calculation of the ratio (pheopigments)/(chlorophyll $a+$ pheopigments) and its representation along a vertical transect showed that during the "Nutrigas" cruise, the percentage of pheopigments were vertically homogeneous, with low values in the central area, indicating a high proportion of fresh phytoplankton throughout the water column as the large diatoms settle rapidly (Fig. 8).

\section{Location of Fig. 8}

The settling of the late winter diatom bloom fits with the model results of Loyer (2001) who found a maximum flux of organic matter to the bottom during the same period. Herlory (2001) also pointed out during this "Nutrigas" cruise the dominance of large diatoms and the absence of mesozooplankton, the only zooplankton group able to graze on large diatoms.

During the late winter, the "ocean color" images also show that the Bay of Vilaine is a coastal area where phytoplankton production starts early (Huret, 2005); river inputs create a thin haline stratification which is favourable for phytoplankton production (Chapelle, 1990). Satellite data also show that this coastal area has lower turbidity than in the Loire river plume, due to the prevalent settling processes in this muddy bay; it is also protected from swell and sediment resuspension by a line of islands.

\subsubsection{The spring situation}

During the spring "Gasprod" cruise, the Loire river flow was moderate and ranged from $571 \mathrm{~m}^{3} \mathrm{~s}^{-1}$ to $421 \mathrm{~m}^{3} \mathrm{~s}^{-1}$. After the late winter phytoplankton bloom, the central area of the northern 
shelf exhibits nutrient depletion, especially in phosphorus (Fig. 9), despite relatively high phosphorus concentration at the river mouth (Fig. 5).

\section{Location of Fig. 9}

These results are similar to those found by Loyer et al. (2006) in the same area. The exhaustion of nutrients in the central area largely results from the previous uptake by the first phytoplankton bloom and low concentration in offshore water. Moreover, the riverine waters that spread over the shelf at the end of winter have N/P ratios which are much higher than the Redfield value, indicating a greater depletion of phosphorus than nitrogen. For example, the four marine stations which exhibited a DIP concentration as low as $0.01 \mu \mathrm{mol} \mathrm{l}^{-1}$ in the surface water have mean DIN and silicate concentrations equal to $6.77 \mu \mathrm{mol} \mathrm{l}^{-1}$ and $1.42 \mu \mathrm{mol} \mathrm{l}^{-1}$, respectively. During the spring cruise, the turnover time of phosphate in the central area appeared to be shorter $(10 \mathrm{~h})$ than that observed in the river plume area, i.e., $500 \mathrm{~h}$. This indicates significant renewed production within the euphotic zone of the central area. Likewise, Maguer and Morin (pers. comm., 2004) pointed out that the ratio between (nitrate uptake)/(dissolved inorganic nitrogen uptake) was lowest values in the central area, indicating uptake of regenerated ammonium by the phytoplankton (Le Corre et al., 1996).

Over the central area where the thermal stratification starts to be established in mid spring, the small forms of micro-algae are largely present, in particular the pico-phytoplankton (Fig. 10b). These small phytoplankton are better competitors for nutrient uptake when present in low concentrations due to their high surface to volume ratio; they are also able to use organic forms of phosphorus (Labry et al., 2002).

\section{Location of Fig. 10}

Contrary to the way the central area functions, the coastal river plumes in the northern Bay are the place of diatom growth because they are continuously enriched by nutrient inputs and the decreasing river flow leads to a lower turbidity. Figure 10a clearly shows the coastal maximum of phytoplankton biomass. The entire upper layer in the river plume exhibited two dominant diatom populations (Chaetoceros sociale, Thalassiosira rotula) above 20 meters with an evident uptake in dissolved inorganic nutrients pointed out by Lunven et al. (2005).

\subsubsection{The summer situation}

During the summer, results were obtained during the "Viloir" cruise; the Loire river flow was low and ranged from $272 \mathrm{~m}^{3} \mathrm{~s}^{-1}$ to $229 \mathrm{~m}^{3} \mathrm{~s}^{-1}$. The maximum biomass of phytoplankton is maintained within smaller river plumes which are still enriched by low nutrient inputs; for instance chlorophyll $a$ concentrations higher than $20 \mu \mathrm{g} \mathrm{l}^{-1}$ were observed in the small Loire river plume in June 2003 (Lunven et al., 2005). During summertime, the phytoplankton production in these plume areas can be nitrogen limited due to a pronounced decrease in riverine nitrogen input and consequently a low N/P ratio at the mouth of estuaries, as seen in chapter 3.2. Chapelle (1990) also noted a summer nitrogen limitation in the Bay of Vilaine.

Towards the open sea, the concentration of chlorophyll $a$ was highest $\left(5 \mu \mathrm{g} \mathrm{l}^{-1}\right)$ in the 2-m pycnocline (Fig. 11). The low DIN concentration $\left(<0.2 \mu \mathrm{mol} \mathrm{l}^{-1}\right)$ likely limited phytoplankton production in the surface layer above the nutricline, and the phytoplankton growth was irradiancelimited below the pycnocline as Lunven et al. ( 2005) shown during the same cruise.

\section{Location of Fig. 11}

A third zone, the accore zone, located on the eastern boundary of the study area, has high episodic phytoplankton production, which is independent of riverine nutrient inputs. Over the shelf break, when the water column is vertically stratified (from May to September), the tide generates internal waves responsible for significant mixing and upwelling of nutrients (Druon, 1998). Satellite imagery (Gohin et al., 2002) was a valuable tool for highlighting the location of phytoplankton production in an area up to $500 \mathrm{~km}$ long and $50 \mathrm{~km}$ wide (Fig. 12). 


\section{Location of Fig. 12}

Albaina and Irigoien (2004) showed that during the stratified period, the episodic high primary production on the shelf break enhances the abundance of the zooplankton which fits well with the described spatial distribution for the zooplanktivorous Biscayan anchovy and marine mammals (Kiszka and Van Canneyt, 2005). In summer the importance of the planktonic production for fisheries resources on the accores contrasts with low phytoplankton biomass of the central area.

\section{Conclusion}

The Loire and Vilaine estuaries are the main continental sources of nutrients to the northern Bay of Biscay. Within the estuarine system, the high turbidity in the macrotidal Loire estuary limits the growth of phytoplankton and favours the conservative nature of nutrients through the estuary to the coastal zone (Monbet, 1992). Concentration of particulate forms of nitrogen and phosphorus throughout the estuary correspond to the dynamics of suspended matter, characterized by retention during low river flow and release during winter floods.

The northern Bay of Biscay seaward of the estuaries is characterized by coastal river plumes and the central area of the shelf.

Before mid-February, insufficient irradiance limits phytoplankton growth over the continental shelf. Satellite ocean color data used by Huret (2005) confirmed that the mean chlorophyll $a$ concentrations calculated in January (applying empirical algorithms to all SeaWiFS data available in January between 1998 and 2004) are lower than $1 \mu \mathrm{g} / \mathrm{l}$.

Near the coast, there is no phytoplankton production in river plumes of the northern Bay before mid-spring because of light limitation from suspended sediment flux from the river and resuspension in the Bay. The inner Bay of Vilaine, which is a nursery area for flatfish (Le Pape et al., 2007), differs from the northern part of the Bay of Biscay, with lower turbidity and earlier phytoplankton blooms in late February. This is due to the high settling process in this muddy bay, linked to the weak residual current (Lazure and Jegou, 1998) and to possible protection from swells by a line of islands (Belle-Ile, Houat, Hoëdic, Quiberon peninsula). The Bay of Vilaine is sensitive to eutrophication and to hypoxic/anoxic events in summer (Chapelle, 1990). The positive influence of riverine nutrient inputs on nursery habitat can be offset by negative impacts from eutrophication.

The large central area of the nortern shelf that supports late winter diatom blooms under specific weather conditions, which correspond to anticyclonic "windows." The concentration of chlorophyll $a$ and the extension of the northern late winter phytoplankton bloom observed in 2001 during the "Nutrigas" cruise, and pointed out by satellite imagery between 1998 and 2004 (Huret, 2005) appear higher that those observed in the southern Bay of Biscay; Herbland et al. (2004) showed that late winter phytoplankton blooms have theorically appeared at least every two years since 1977, when anticyclonic conditions in the northern Bay of Biscay coincide with haline stratification periods produced by a 3D hydrodynamic model of Lazure and Jegou (1988). The settling of the large diatoms, as predicted by Turner (2002), supports high secondary production in the form of demersal fisheries in the muddy sand bottom, called "La Grande Vasière" (Le Loc'h, 2004), of the central area. This rich area in the northern Bay of Biscay is larger than those located in front of the Gironde estuary.

After the late winter bloom, the central area of the shelf quickly becomes depleted in phosphorus and the euphotic zone is characterized by low nutrient levels and predominance of small phytoplankton. During the spring "Gasprod" cruise, Sautour (pers. comm., 2004) noted high grazing rates by microzooplankton on the picophytoplankton, similar to the Gironde plume in spring (Sautour et al., 2000); they concluded that under these conditions most of the phytoplankton biomass was recycled within the euphotic layer. There was a weak vertical export of particulate organic matter, contrary to late winter, when diatoms sink (Herbland et al., 1998). Finally the western shelf break, the accores, has episodic high phytoplankton biomass related to upwelled nutrients from internal waves, which could support important pelagic fisheries resources. 


\section{Acknowledgments}

This research was supported by the Programme National d'Environnement Côtièr (Chantier Atlantique) with additional funding from the IFREMER Program "Grand Défi Golfe de Gascogne". Thanks are due to the crews of R/V Thalassa and R/V Côtes de la Manche. We wish to thank P. Bodenes, M.-P. Crassous, M.-M. Danielou, R. Kerouel, E. Le Gall, J. Le Grand, X. Philippon and A. Youenou for their technical work throughout the study. We also wish to thank N. N. Rabalais and the another reviewer for their valuable comments. 


\section{References}

Albaina, A. and Irigoien, I., 2004. Relationships between frontal structures and zooplankton communities along a croos-shelf transect in the Bay of Biscay (1995 to 2003). Marine Ecology Progress Series, 284: 65-75.

Aminot, A., Guillaud, J.-F., Andrieux-Loyer, F., Kerouel, R. and Cann, P., 1998. Apports de nutriments et développement phytoplanctonique en baie de Seine. Oceanologica Acta, 21 (6): 923-935.

Aminot, A., Guillaud, J.-F., and Andrieux, F., 1993. Spéciation du phosphore et apports en baie de Seine orientale. Oceanologica Acta, 16 (5-6): 617-623.

Chapelle, A., 1990. Modélisation d'un écosystème marin côtier soumis à l'eutrophisation : la baie de Vilaine (sud-Bretagne). Etude du phytoplancton et du bilan en oxygène. Thèse Univ. Paris VI, $201 \mathrm{p}$.

Cloern, J. E., 2001. Our evolving conceptual model of the coastal eutrophication problem. Marine Ecology Progress Series, 210: 223-253.

Conley, D. J., 2000. Biogeochemical nutrient cycles and nutrient management strategies. Hydrobiologia, 410: 87-96.

Dolezal, F. and Kvitec, T., 2004. The role of recharge zones, discharge zones, springs and tile drainage systems in peneplains of Central European highlands with regard to water quality generation processes. Physics and Chemistry of the Earth, 29: 775-785.

Druon, J.-N., 1998. Modélisation d'écosystèmes pélagiques dans le proche Atlantique. Interactions entre les phénomènes physiques et biologiques. Thèse Univ. ParisVI, 228 p.

Gallenne, B., 1974. Les accumulations turbides de l'estuaire de la Loire. Etude de la crème de vase. Thèse Univ. Nantes. $323 \mathrm{p}$.

Gohin, F., Druon, J.N. and Lampert, L,. 2002. A five channel chlorophyll concentration algorithm applied to SeaWiFS data processed by SeaDAS in coastal waters. International Journal of Remote Sensing, 23: 1639-1661.

Gohin, F., Lampert, L., Guillaud, J.-F., Herbland, A.and Nezan, E., 2003. Satellite and in situ observations of a late winter phytoplankton bloom in the northern Bay of Biscay. Continental Shelf Research, 23: 1117-1141.

Guillaud, J.-F., Andrieux, F. and Menesguen, A., 2000. Biogeochemical modelling in the Bay of Seine (France): an improvement by introducing phosphorus in nutrient cycles. Journal of Marine Systems, 25 (3-4): 369-386.

Guillaud, J.-F., 1983. Les flux de sels nutritifs dans l'estuaire de le Seine (France) ; rôle et importance du bouchon vaseux au cours du mélange estuarien. Canadian Journal of Fisheries and Aquatic Sciences, 40 (1): 180-187.

Hem, J.D., 1989. Study and interpretation of the chemical characteristics of natural water: USGS Water-Supply Paper 2254, $264 \mathrm{p}$

Herbland, A., Delmas, D., Laborde, P., Sautour, B. and Artigas, F., 1998. Phytoplankton spring bloom of the Gironde plume waters in the Bay of Biscay: early phosphorus limitation and food-web consequences. Oceanologica Acta, 21 (2): 279-291.

Herbland, A., Delmas, D., Gohin, F. and Lazure, P., 2004. Winter phytoplankton blooms in the Bay of Biscay: Retrospective study of space-time windows favourable to their release. Potential ecological consequences. Technical note, IFREMER (France) unpublished, $4 \mathrm{p}$.

Herlory, O., 2001. Etude de la dynamique du zooplancton à l'aide d'un compteur optique de plancton : Applications à des suivis temporels en point fixe, et à des distributions spatiales dans le Golfe de Gascogne. Développement méthodologiques. DEA, Univ Bordeaux, Laboratoire d’Océanographie Biologique, Station Marine, Arcachon (France). Unpublished report, 35 p.

Holm-Hansen, O., Lorenzen, C.J., Holmes, R.W. and Strickland, J.D.H., 1965. Fluorometric determination of chlorophyll. ICES Journal, 30: 3-15.

Huret, M., 2005. Apport des données “couleur de l'eau” à la modélisation couplée physiquebiogéochimie en milieu dynamique côtier. Application au Rio de la Plata et au Golfe de Gascogne. Thèse Univ. Toulouse III, 274 p. 
Jarvie, H. P., Neal, C., Withers, P. J. A., Wescott, C. and Acornlay, M., 2005. Nutrient hydrochemistry for a groundwater-dominated catchment: The Hampshire Avon, UK. Science of the Total Environment, 344: 143-158.

Kemp, W. M. and 17 authors, 2005. Eutrophication of Chesapeake Bay: historical trends and ecological interactions. Marine Ecological Progress Series, 303:1-29.

Kiszka, J. and Van Canneyt, O., 2005. Les cétacés dans le golfe de Gascogne : diversité et distribution. Le Courrier de la Nature, SNPN, $217: 22-29$.

Kérouel, R., Aminot, A., 1997. Fluorimetric determination of ammonia in sea and estuarine waters by direct segmented flow analysis. Marine Chemistry, 57: 265-275.

Köhler J., 2006. Detergentphosphate: an EU policy assessment. Journal of business chemistry, 3 (2):15-21.

Koutsikopoulos, C. and Le Cann, B., 1996. Physical processes and hydrological structures related to the Bay of Biscay anchovy. Scientia Marina, 60 (2-Suppl.): 9-19.

Labry, C., Herbland, A., Delmas, D., Laborde, P., Lazure, P., Froidefond, J.M., Jegou, A.M. and Sautour, B., 2001. Initiation of winter phytoplankton blooms within the Gironde plume waters in the Bay of Biscay. Marine Ecology Progress Series, 212: 117-130.

Labry, C., Herbland, A. and Delmas, D., 2002. The role of phosphorus on planktonic production of the Gironde plume waters in the Bay of Biscay. Journal Plankton Research, 24 (2): 97-117.

Lampert, L., Quéguiner, B., Labasque, T., Pichon, A. and Lebreton, N., 2002. Spatial variability of phytoplankton composition and biomass on the eastern continental shelf of the Bay of Biscay (north-east Atlantic Ocean). Evidence for a bloom of Emiliana huxleyi (Pprymnesiophyceae) in spring 1998. Continental Shelf Research, 22: 1225-1247.

Lazure, P. and Jegou, A.-M., 1998. 3D modelling of seasonal evolution evolution of Loire and Gironde plumes on Biscay Bay continental shelf. Oceanologica Acta, 21: 165-177.

Le Corre, P., Wafar, M., L'Helguen, S. and Maguer, J.F., 1996. Ammonium assimilation and regeneration by size-fractionated plankton in permanently well-mixed temperate waters. Journal of Plankton Research, 18: 355-370.

Le Loc'h, F., 2004. Structure, fonctionnement évolution des communautés benthiques des fonds meubles exploités du plateau continental Nord Gascogne. Thèse Univ. Bretagne Occidentale, $326 \mathrm{p}$.

Le Pape, O., Baulier, L., Cloarec, A., Martin, J., Le Loc'h, F., Désaunay Y. 2007. Habitat suitability for juvenile common sole (Solea solea, L.) in the Bay of Biscay (France): A quantitative description using indicators based on epibenthic fauna. Journal of Sea Research, 57: 126-136.

Loyer, S., 2001. Modélisation de la production phytoplanctonique dans la zone côtière atlantique enrichie par les apports fluviaux, Thèse de Doctorat de l’Université de Paris VI, 232 p.

Loyer, S., Lampert, L., Ménesguen, A., Cann, P. and Labasque, T., 2006. Seasonal evolution of the nutrient pattern on Biscay Bay continental shelf over the years 1999-2000. Scienta Marina, 70 (1): 31-46.

Lunven, M., Guillaud, J.-F., Youenou, A., Crassous, M.-P., Berric, R., Le Gall, E., Kerouel, R., Labry, C.and Aminot, A., 2005. Nutrient and phytoplankton distribution in the Loire River plume (Bay of Biscay, France) resolved by a new Fine Scale Sampler. Estuarine Coastal and Shelf Science, 65 (1-2): 94-108.

Monbet, Y., 1992. Control of phytoplankton biomass in estuaries: a comparative analysis of microtidal and macrotidal estuaries. Estuaries, 15: 563-571.

Morin, P., Le Corre, P., Le Marty, Y. and L'Helguen, S., 1991. Spring evolution of nutrients and phytoplankton on the Armorican shelf (North-West European shelf). Oceanol. Acta, 14 (3): 263-279.

Nausch, G., Nerhing, D. and Aertebjerg G., 1999. Anthropogenic nutrient load of the Baltic Sea. Limnologica, 29: 233-241.

OSPAR Commission 2000. Quality Status Report 2000: Region IV - Bay of Biscay and Iberian Coast. OSPAR Commission, London 134 + xiii pp.

Peeters, J. C. H. and Peperzak, L., 1990. Nutrient limitation in the North Sea: a bioassay approach. Netherlands Journal of Sea Research, 26 (1): 61-73. 
Puillat, I., Lazure, P., Jégou, A.-M., Lampert, L. and Miller, P.I., 2004. Hydrographical variability on the French continental shelf in the Bay of Biscay, during the 1990s. Continental Shelf Research, 244: 1143-1163.

Rincé Y., Guillaud, J.-F. and Gallenne, B., 1985. Qualité des eaux en milieu estuarien : suivi annuel de critères physiques et chimiques dans les eaux de l'estuaire de la Loire. Hydrobiologia, 124: 199-210.

Riley, G.A., 1957. Phytoplankton of the North Central Sargasso Sea. Limnology and Oceanography, 2: 252-270.

Sautour, B., Artigas, L. F., Delmas, D., Herbland, A. and Laborde, P. 2000. Grazing impact of microand meso-zooplankton during a spring situation in coastal waters off the Gironde Estuary. Journal of Plankton Research, 22 (3): 531-552.

Sigleo, A. and Frick, W. Modeling seasonal variations in river flow and nutrients in a northeastern Pacific estuary. Estuaries (in press).

Thingstad, T. F., Skjoldal, E. F. and Bohme, R. A. 1993. Phosphorus cycling and algal-bacterial competition in Sandsfjord, western Norway. Marine Ecology Progress Series, 99: 239-259.

Tréguer, P. and Le Corre, P., 1975. Manuel d'analyse des sels nutritifs dans l'eau de mer. Université de Bretagne Occidentale, Brest, France 110 pp.

Turner, J. T., 2002. Zooplankton fecal pellets, marine snow and sinking phytoplankton blooms. Aquatic Microbial Ecology, 27: 57-102.

Vollenweider, R.A., Giovanardi,F., Montanari, G. and Rinaldi A., 1998. Characterisation of the trophic conditions of marine waters with special reference to the NW Adriatic Sea: Proposal for a trophic scale, turbidity and generalised water quality index. Environmetrics, 9: 329-357.

Wassmann, P. And Olli, K., 2004. Drainage basin nutrient and eutrophication: an integrated approach. University of Tromso, Norway, 325 pp. 
Table 1: values of annual nutrient fluxes $\left(\mathrm{t}^{-1}\right)$ in 2004 by Loire and Vilaine rivers

\begin{tabular}{cccc}
\hline \multirow{2}{*}{ Rivers } & \multicolumn{3}{c}{ Nutrient fluxes in $2004\left(\mathrm{t} \mathrm{y}^{-1}\right)$} \\
\cline { 2 - 4 } & DIN & DIP & Si \\
\hline Loire & 115000 & 3100 & 125000 \\
\hline Vilaine & 15000 & 160 & 9000 \\
\hline
\end{tabular}




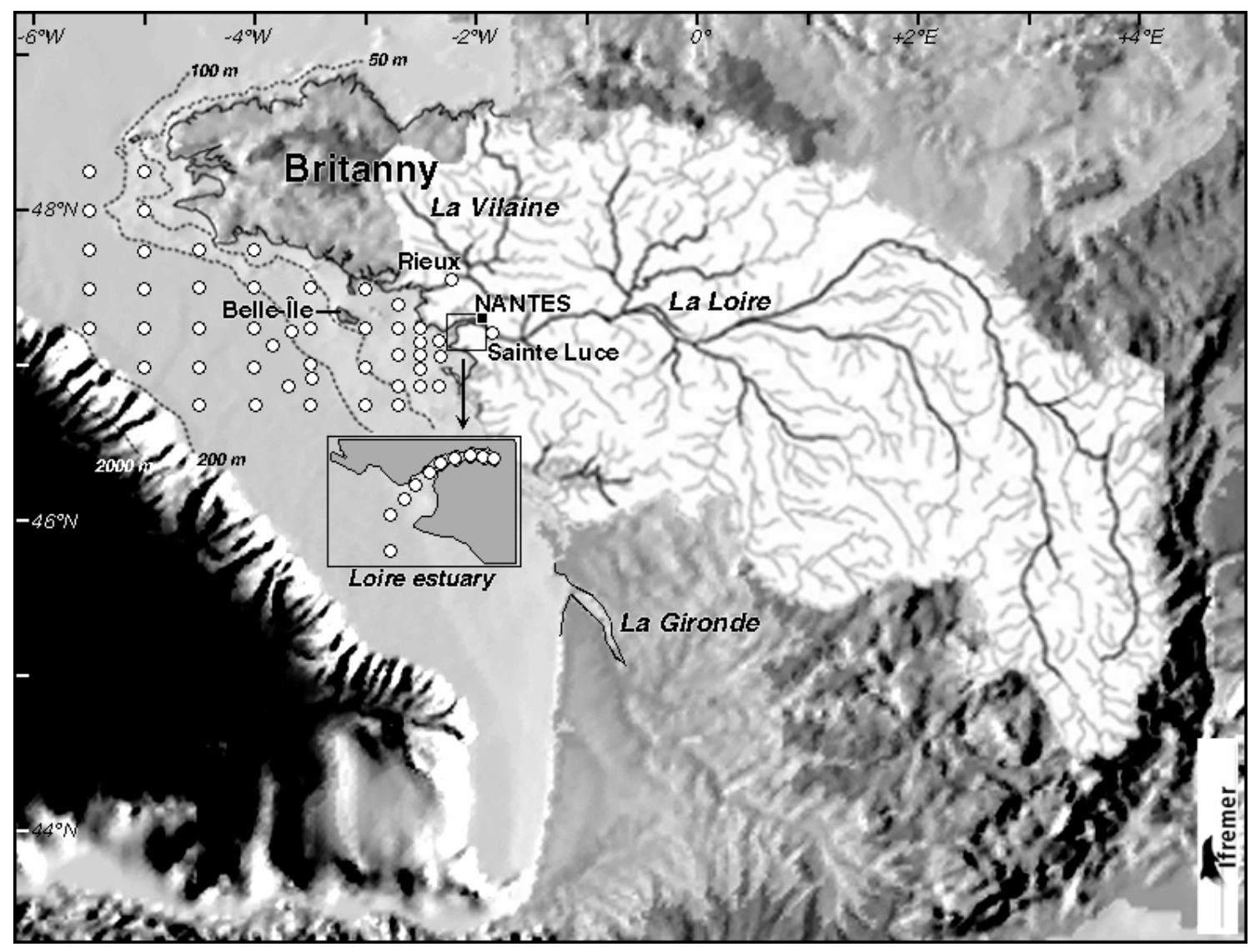

Fig. 1 : The Loire and Vilaine river basins, and the network of stations sampled in the northern Bay of Biscay during "Nutrigas" and "Gasprod" cruises. Rieux and Sainte-Luce are where freshwater samples were taken in the Vilaine and Loire rivers, respectively. 


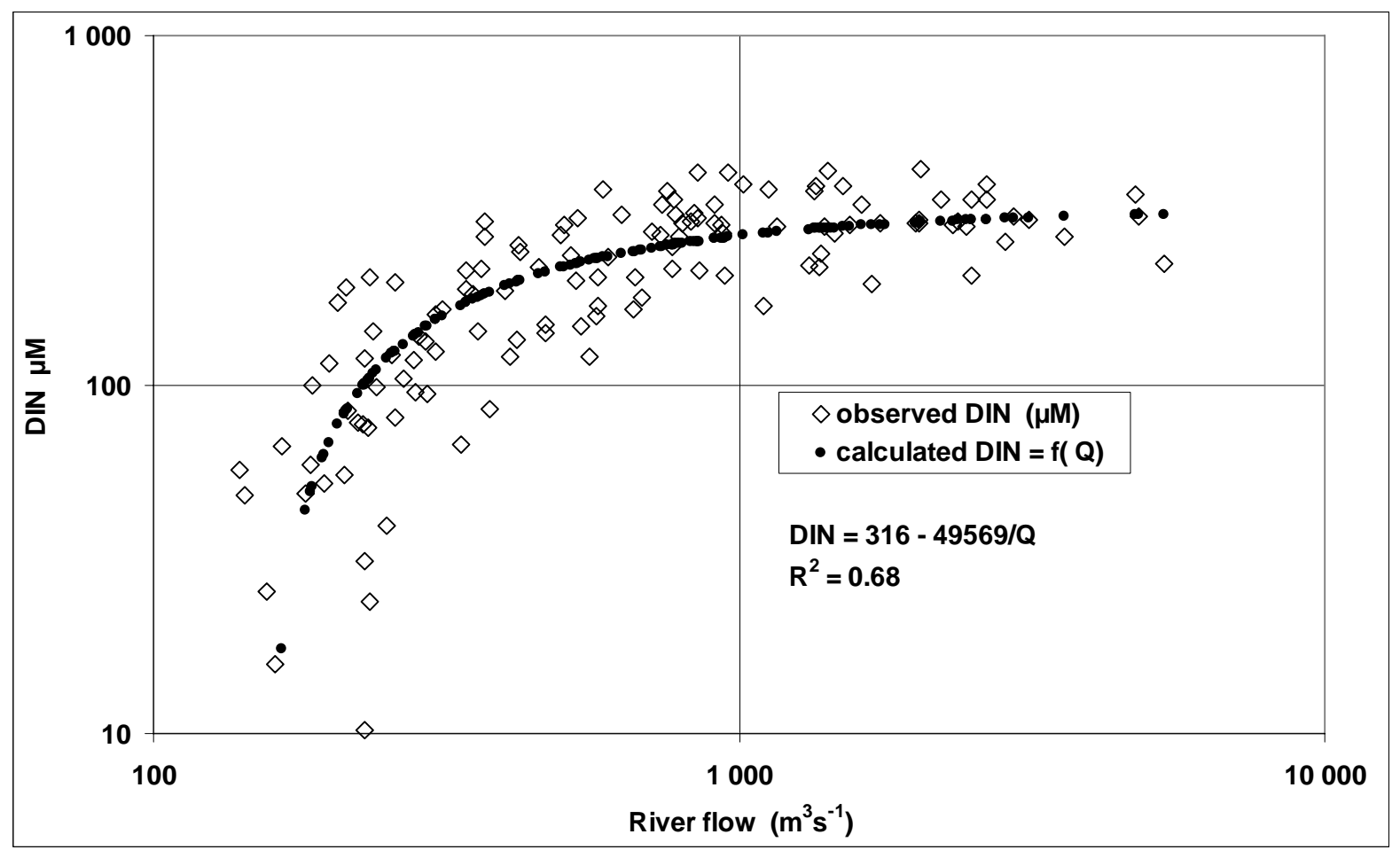

Fig. 2: Relationship between Dissolved Inorganic Nitrogen (DIN) and river flow of the Loire river 


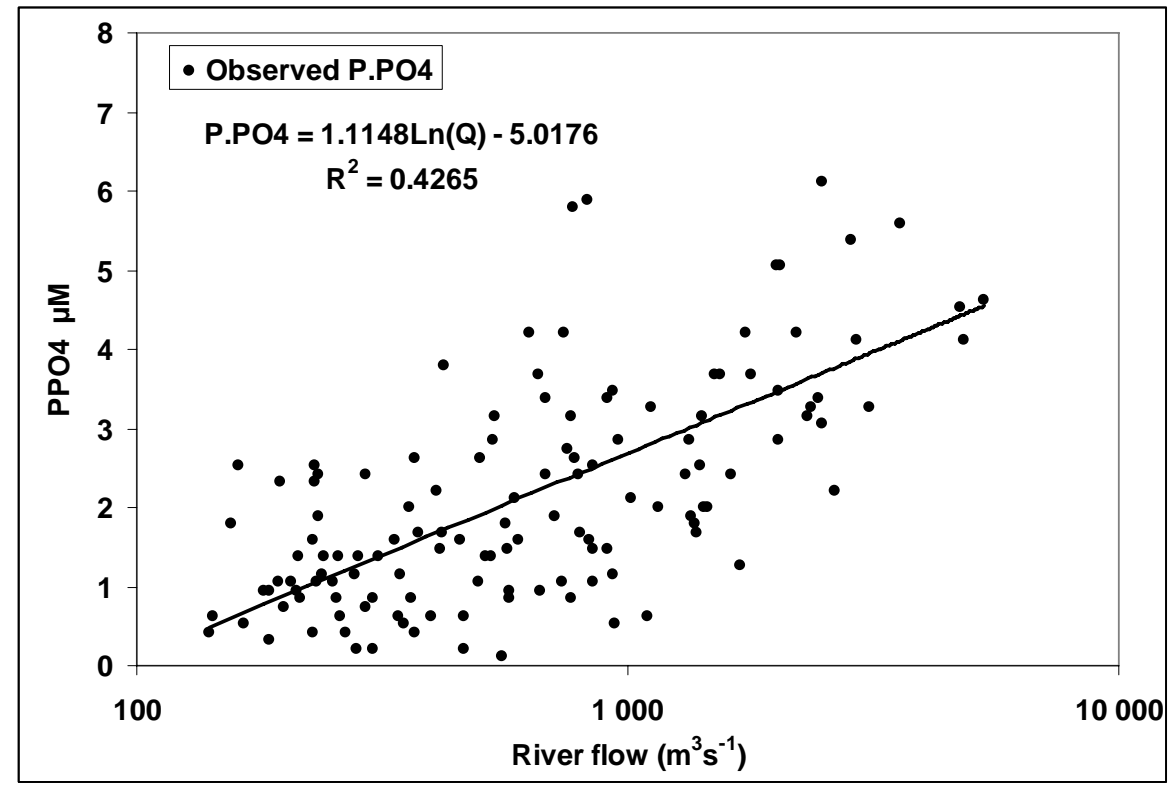

Fig. 3: Relationship between Dissolved Inorganic phosphorus (DIN) and river flow of the Loire river 


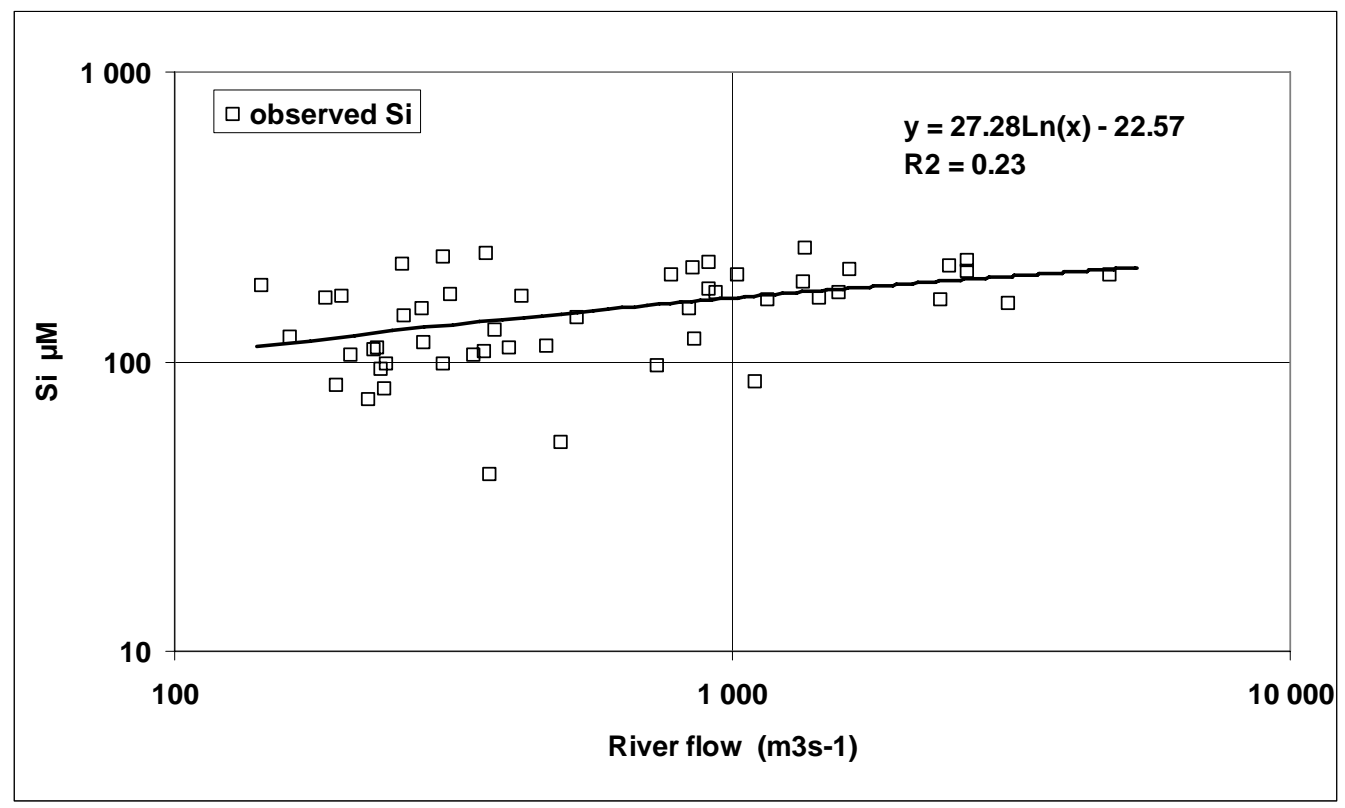

Fig. 4: Relationship between the ratio N/P in fresh water and the Loire river flow 


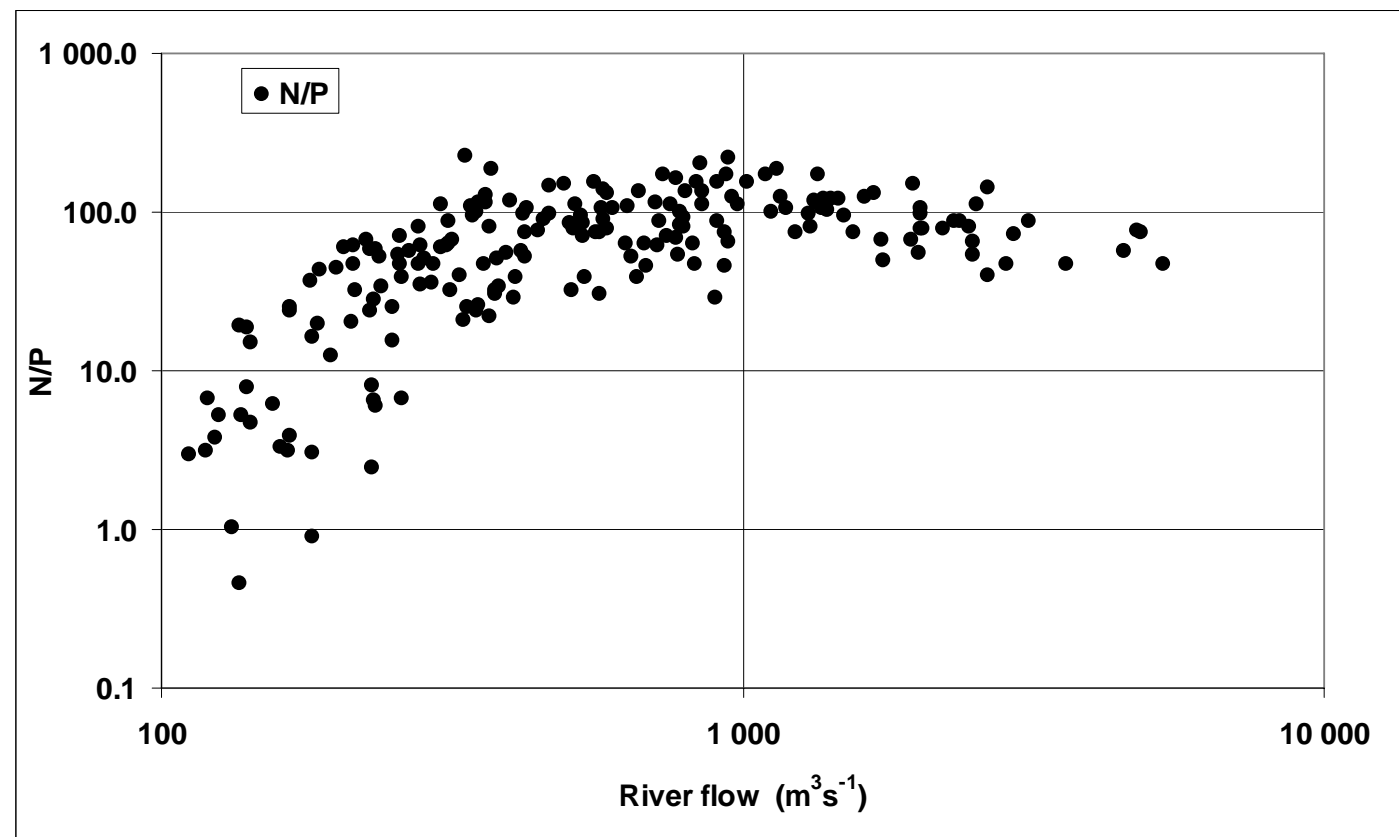

Fig. 5: Relationships between N/P molar ratio in the Loire river and (a) the river flow, and (b) the year 

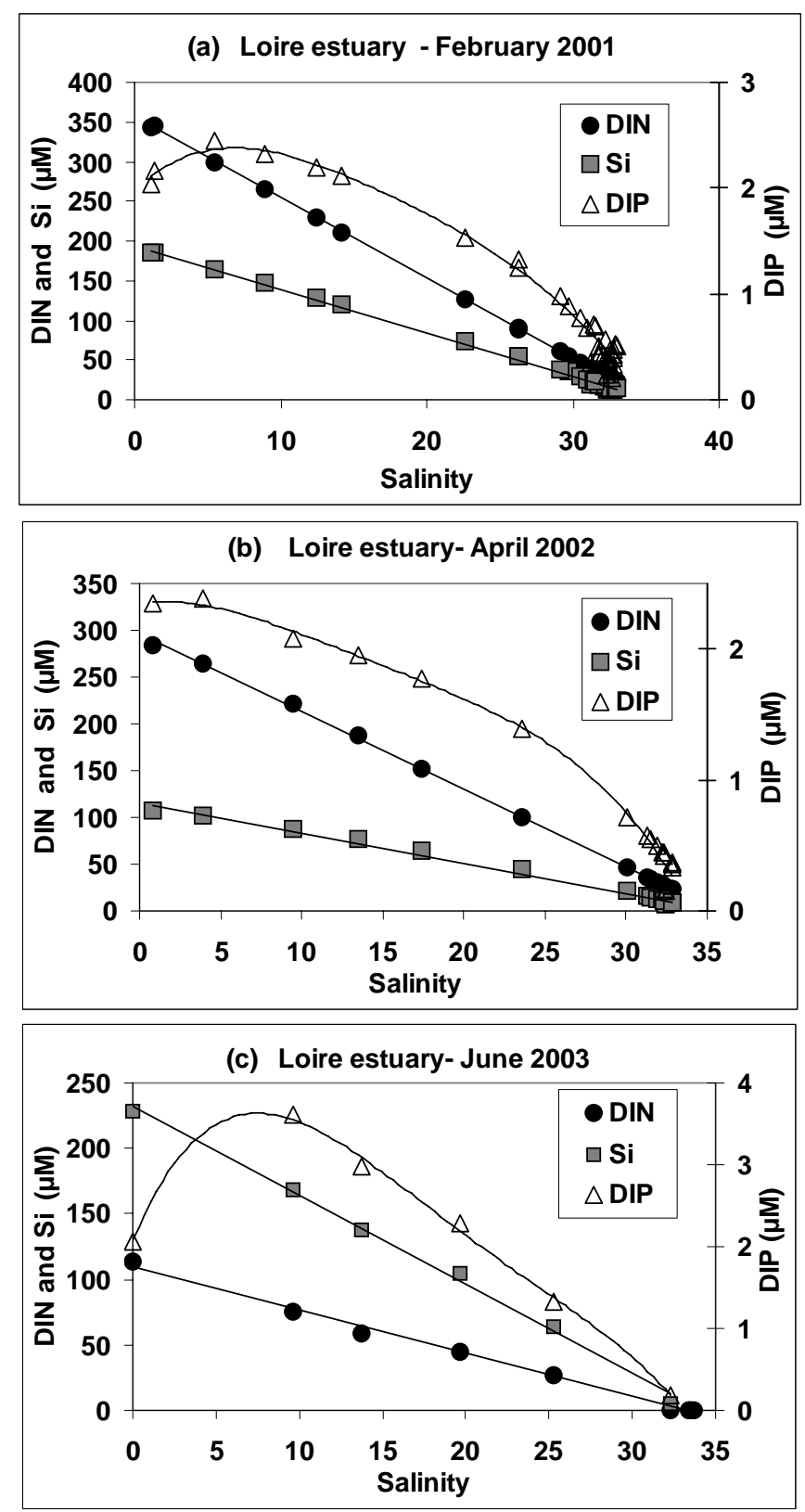

Fig. 6: Relationship between nutrients and salinity in the Loire estuary in (a) February 2001, (b) April 2002 and (c) June 2003. 


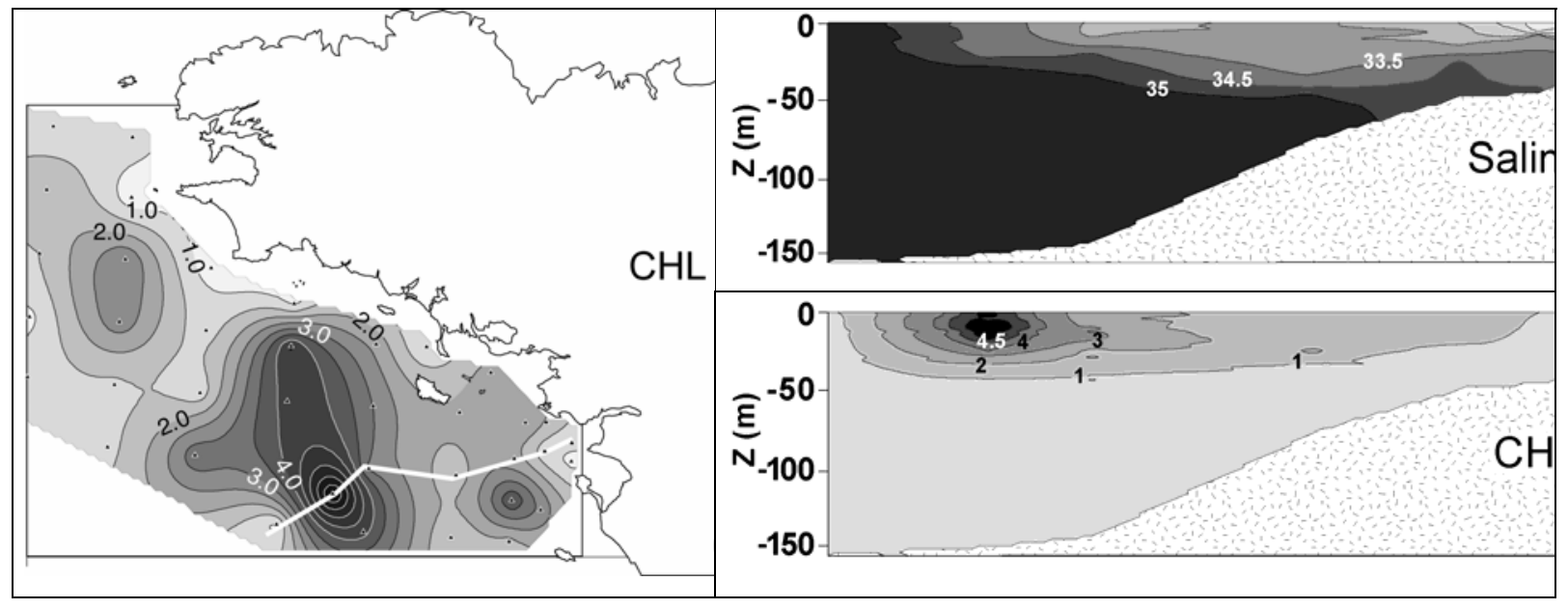

Fig. 7: (a) Chlorophyll $a$ concentrations ( $\mu \mathrm{g} \mathrm{l}^{-1}$ ) in surface water (February 2001), (b) salinity along the vertical transect drawn on the preceding map and (c) chlorophyll $a\left(\mu \mathrm{g} \mathrm{l}^{-1}\right)$ along the same transect. 


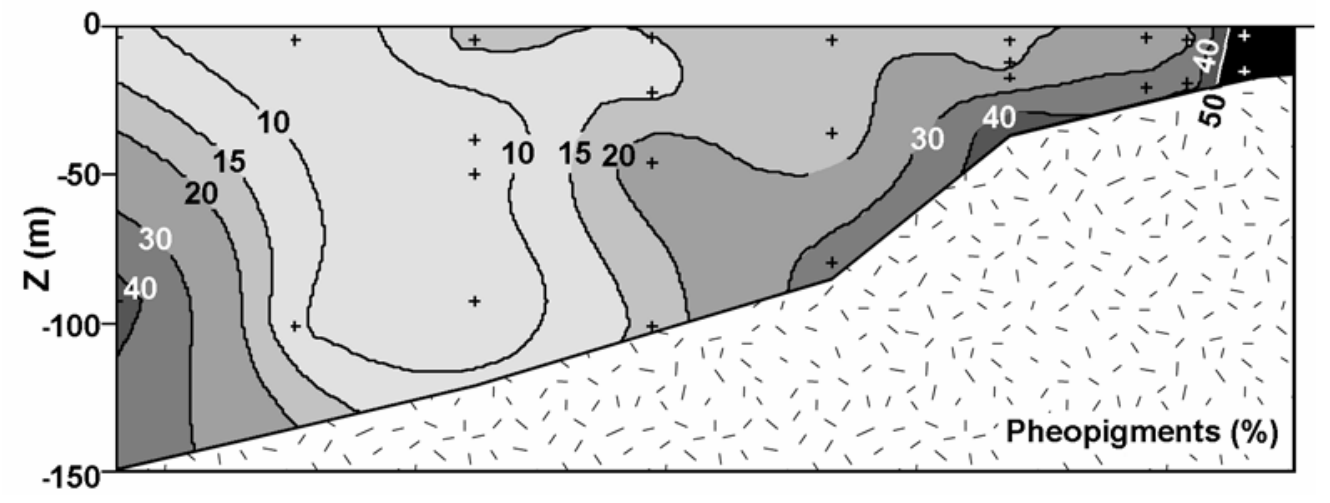

Fig. 8: Percentage of pheopigments in February 2001 along the vertical transect shown in fig. 7.

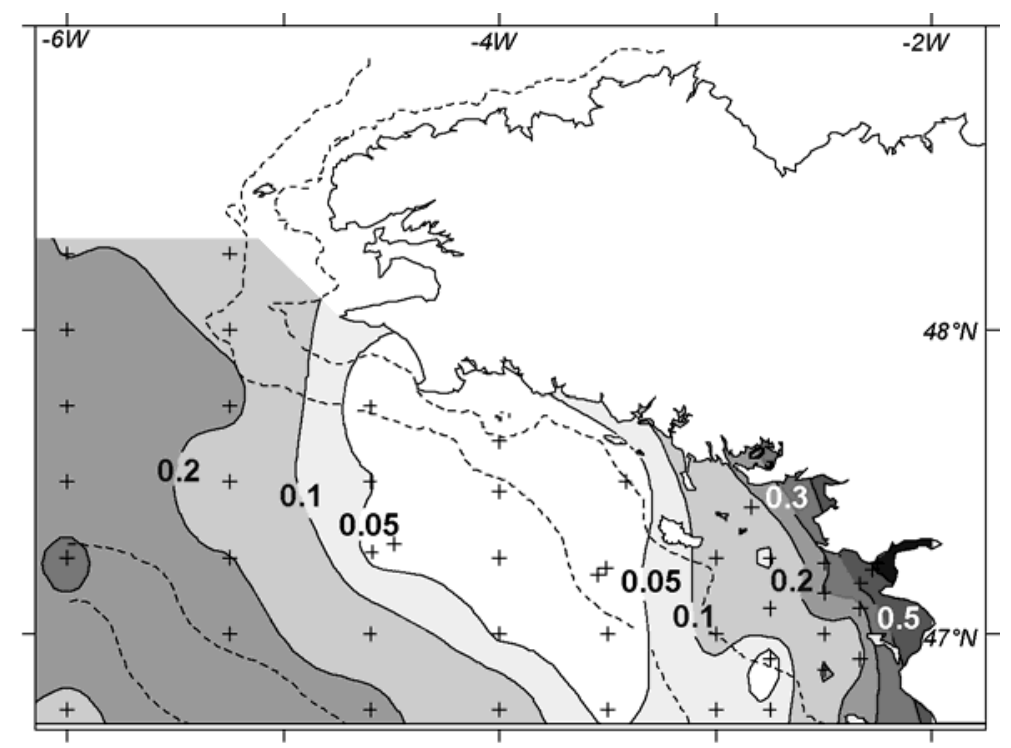

Fig. 9: Dissolved Inorganic Phosphorus (DIP) concentrations $(\mu \mathrm{M})$ in the surface water of the northern Bay of Biscay in April 2002. 


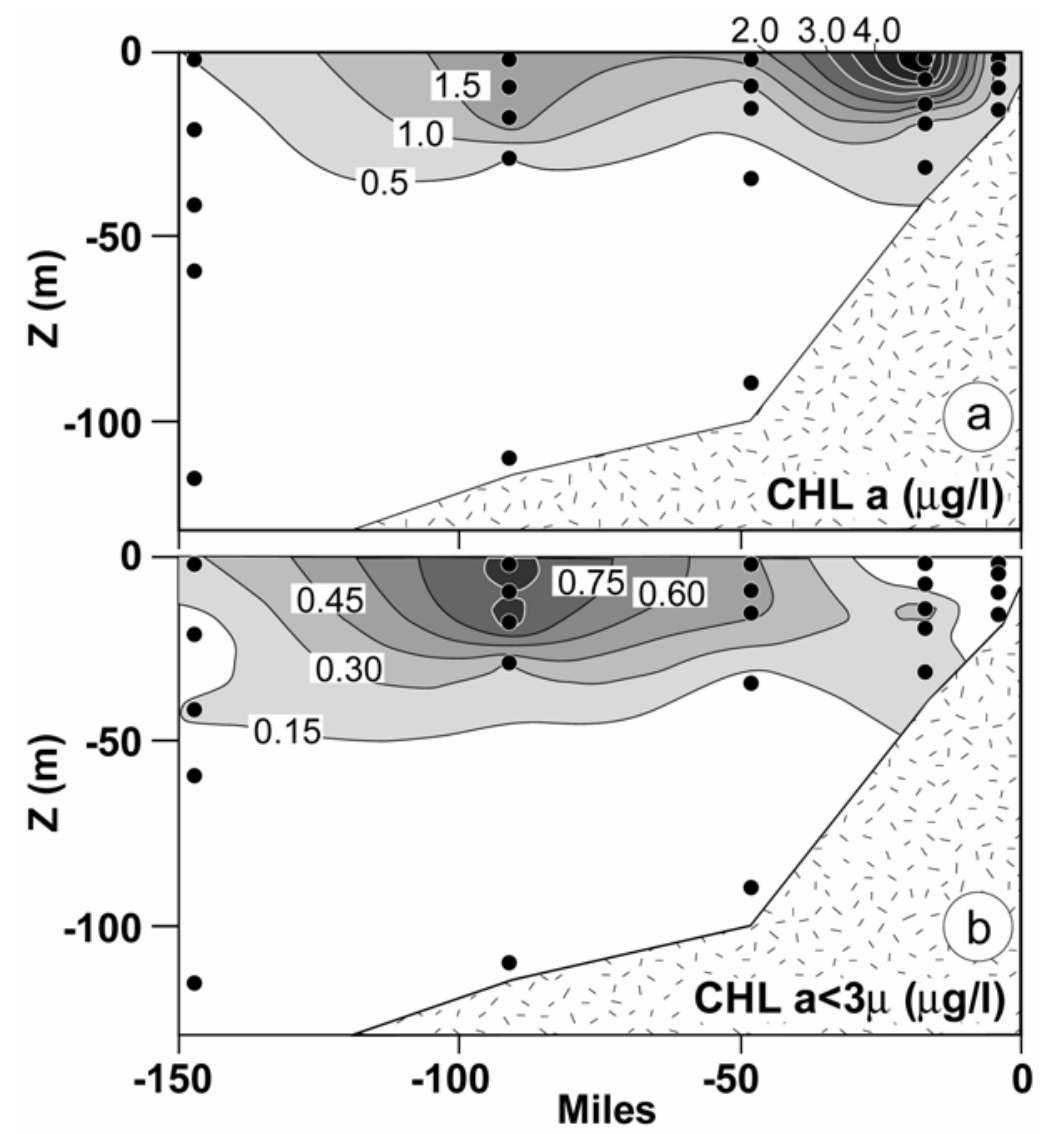

Fig. 10: (a) Total chlorophyll $a\left(\mu \mathrm{g}^{-1}\right)$ and (b) chlorophyll $a\left(\mu \mathrm{g}^{-1}\right)$ of the pico-phytoplankton in April 2002 along the vertical transect shown in fig. 7.

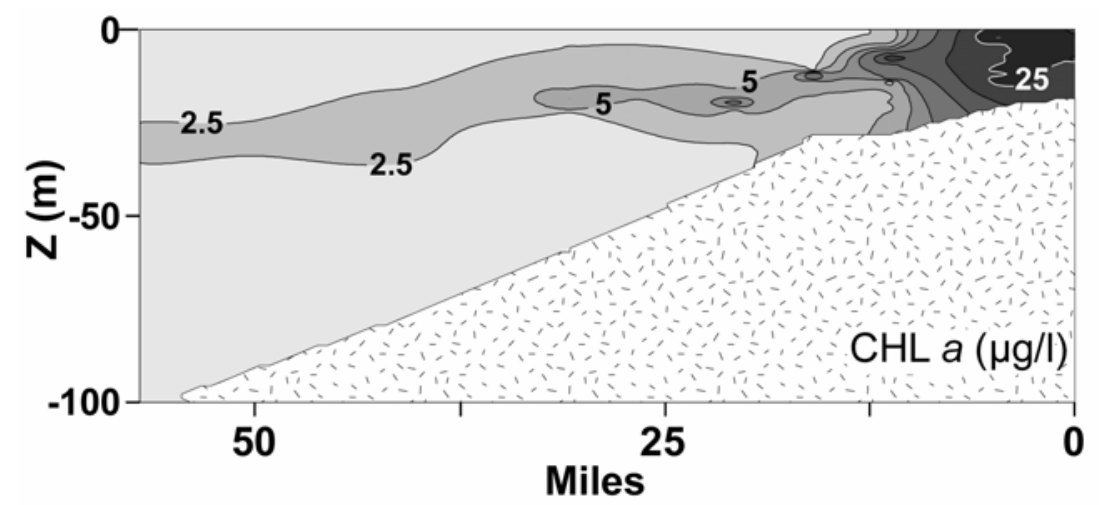

Fig. 11: Chlorophyll $a$ concentrations $\left(\mu \mathrm{g} \mathrm{l}^{-1}\right.$ ) in June 2003 along the eastern part of the vertical transect drawn on fig. 7. 


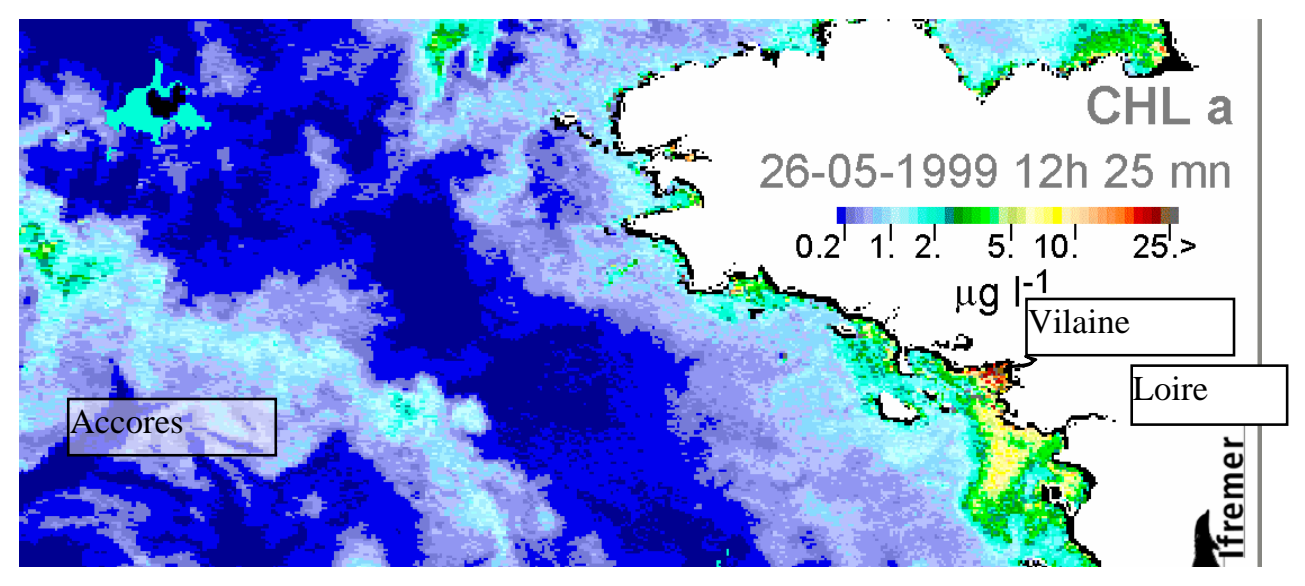

Fig. 12: Chlorophyll $a$ concentrations in May 1999 derived from SeaWiFS satellite data [application of a specific algorithm given by Gohin et al. (2002)]. 